\title{
Legal and Regulatory Framework of Islamic Banking and Finance: A Study in Singapore
}

Ledy Mahara Ginting,

Nafisah Ruhana,

Nur Haziyah Haji Abdul Halim,

Salsabilla Terra Finieli

\section{International Islamic University Malaysia}

\begin{abstract}
:
The aim of this paper is to examine the Islamic Banking and Finance (IBF) industry in Singapore. Singapore is known to be a global financial hub with a resilient economy for capital flow. As a Muslim minority country, the Islamic finance industry in Singapore is established and fairly stable. This study analyses Singapore's legal and regulatory framework of IBF to review the legal and regulatory framework which promotes the development of Islamic finance in Singapore. IBF in Singapore has been treated equally as the conventional banking under the same regulatory framework, with little guidelines on Shariah governance in the country. This paper concludes that the Singaporean government adopts a flexible approach in regulating IBF in Singapore, with little interventions on Shariah matters.
\end{abstract}

Keywords: Legal System; Regulatory Framework; Islamic Banking and Finance; Singapore; Monetary Authority of Singapore 


\section{Introduction}

Singapore is a small country situated in Southeast Asia with an area of 721.5 square kilometres. Having a strategic location at the edge of the Malaysian peninsula and heavily urbanized, Singapore is known to be the global financial hub with an advanced financial industry in shaping a resilient economy for capital flow. Singapore is also renowned as one of the countries that have an excellent international financial sector. This is evidenced by Kuwait Finance Report (2013) which described Singapore as an international player having high regulatory standards for its financial sector. With its expertise in the financial sector, Singapore is capable to meet various financing needs, particularly through its liquid capital market.

With these advantages, the Islamic Banking and Finance (IBF) industry in Singapore is expected to develop successfully though Singapore as a secular and non-Muslim country which has faced several issues pertaining to the practice of IBF. Claimed to be unable to achieve economies of scale, Islamic banks in Singapore have not received much preference as compared to its conventional counterpart. Furthermore, Kepli (2013) highlighted that the current secular common law practiced by Singapore may contribute to some legal and regulatory constraints in the documentation of Islamic financial transactions.

Singapore continues to strive to optimize the legal and regulation framework for IBF to be implemented well. Singapore with its world-class financial infrastructure and connectivity is no exception but to embark into IBF to secure and build upon the country's aspiration as an international financial hub by releasing several compliance requirements for IBF. This country has shown several signs of progress and development in implementing IBF. Several Islamic financial products have been introduced by financial institutions in Singapore. In 2005, Monetary Authority of Singapore was upgraded to a Full Member of the Islamic Financial Services Board (IFSB) in December 2003 (IFSB, 2005). Furthermore, Singapore has also involved in several Islamic investment activities.

This study evaluates Singapore's legal and regulatory framework of IBF. This study also explores the growth, development, and prospects of IBF in Singapore. Hence, this study is descriptive in nature that aims: (i) to identify the legal and regulatory framework of IBF in Singapore; and (ii) to investigate Shariah governance in Singapore.

The rest of the paper is structured as follows: section two presents literature reviews on the legal context and regulatory framework of IBF in Singapore. Section three discusses the existing legal framework for IBF dispute in Singapore. Section four describes the growth and development of Islamic finance in Singapore, followed by recommendation and conclusion in section five.

International Journal of Management and Applied Research, 2019, Vol. 6, No. 4 


\section{Islamic Banking and Finance in Singapore: Legal Context}

\subsection{Regulatory regime for Islamic banking and finance in Singapore}

The regulatory regime for Islamic banking and finance in Singapore is different in comparison to other jurisdictions. Currently, Singapore has no specific law on Islamic finance. The Singaporean Government takes a fine-tuning approach to accommodate both Islamic and conventional banking within a common regulatory framework. This approach depends on the perfecting process of the existing regulations, rather than making new separate regulations. Therefore, there is only a single legal framework for existing banking and finance system in Singapore regardless of whether it is Islamic or conventional in nature. The sole regulator for banking and finance system in Singapore is Monetary Authority of Singapore (MAS). MAS is the Central Bank of Singapore and monitors the development of banking and finance industry. Along the process of establishing Islamic banking and finance in Singapore, a series of amendments are made to the existing laws to allow for the operation of Islamic banking and finance (Thomas, 2011).

In Singapore, there is an absence of a specific Shariah advisory council at the level of their Central Bank. Each of Islamic financial institutions that are carrying Islamic banking business in Singapore has the responsibility to appoint their internal Shariah Advisory Board to ensure the banking activities comply with Shariah principles. To a great extent, the absence of national Shariah board does not affect the growth of Islamic banking in the country.

A closely related statutory board is Majlis Ugama Islam Singapore (the Islamic Religious Council of Singapore, also known as MUIS). However, MUIS only has the jurisdiction as allowed under the Administration of Muslim Law Act 1966 to interpret the Islamic law within the ambit of Muslim personal law. Since the matter of banking and finance falls under the civil matter, MUIS does not have any authority to make any resolution for Islamic financial institutions or MAS. Even if MUIS comes out with an Islamic ruling or fatwa relating to banking and finance, such ruling can be considered as a piece of advice to be followed, but not binding according to the existing laws.

\subsubsection{Legal system of Singapore}

Singapore does not have separate Islamic banking legislation; the relevant legislations governing Islamic banking in Singapore include Banking Act and Securities and Futures Act (Thomas, 2012). Just like conventional banks, Islamic banks in Singapore must comply with the same requirements set out in the Banking Act and under prudential supervision by the central bank of Singapore. Islamic banks also must meet statutory requirements such as minimum capital requirement, capital adequacy ratio, and paid-up capital.

As a secular country that implements IBF, Singapore has a legal and regulatory framework that is applied to enable the application of IBF. The Singaporean government adapts its existing banking regulations to accommodate Islamic banking (Thomas, 2012). These amendments are necessary to offer Shariah compliant financial products. For example, banks in Singapore were not allowed to engage in non-

International Journal of Management and Applied Research, 2019, Vol. 6, No. 4 
financial businesses, which posed a challenge for Islamic banks to offer financial products that involves the bank to purchase asset and resell it to the customer; the amendment on Banking Act allows Islamic banks to engage in non-financial businesses and offer Shariah compliant products (Kelpi, 2013).

\subsubsection{Legal standing for Islamic banking and finance in Singapore}

The initial legislation for IBF industries in Singapore is Banking Act 1970 (revised 2008) which is the foundation of operational banking industries. In addition, Singapore also has several Acts which are the basis of other Islamic financial industries such as capital market services and financial advisory services that are regulated based on the Securities and Futures Act (Chapter 289) and the Financial Advisers Act (Chapter 110) respectively. Therefore, both conventional and Islamic financial systems are governed under the same regulatory framework. Hence, Islamic banks are being treated the same as conventional.

\subsubsection{Monetary Authority of Singapore (MAS)}

MAS is the central bank of Singapore that aims to promote the growth economic as well as non-inflationary by providing monetary policy and to control macroeconomic of new developing trends and other potential vulnerabilities. As the highest authority, MAS also regulates and supervises both Islamic banking and conventional banking in Singapore by publishing the MAS Guidelines. For Islamic banking, MAS issued the Guidelines on the Application of Banking Regulations to Islamic Banking in 2010 to provide guidance on the regulation of Islamic banking in Singapore. The guidelines only cover the application of the banking regulations, and do not cover the application of other financial legislations such as Financial Advisers Act. MAS also had set the capital requirement for Islamic banking which exactly the same as conventional capital standards. Thus, all products offered in the market are uninformed within similar structures.

MAS is also registered as a member of the international Islamic finance body. In 2005, MAS officially joined as an IFSB member and is now also registered with several international working groups in task forces specifically for Islamic finance such as the Islamic Money Market Taskforce, the Supervisory Review of the Process Working Group and the Special Issues in the Capital Adequacy Working Group.

\subsection{Compliance requirements for Islamic banking and finance in Singapore}

In carrying out the IBF industry, market players must comply with such things that governed by regulators to ensure industries are doing activities in line with Shariah. In term of Shariah advisory, Singapore recognizes a system where the position of Shariah advisor is in industry level only with no highest authority to monitor and make Shariah standard.

\subsubsection{MAS Guidelines}

In facilitating the growth of IBF in Singapore, MAS has issued the 'Guidelines on the Application of Banking Regulations to Islamic Banking' (MAS, 2009). Generally, it provides guidance to banks on the regulations of conducting Islamic banking in Singapore. It combines several regulations issued by MAS which emphasizes on

International Journal of Management and Applied Research, 2019, Vol. 6, No. 4 
specific information relating to the conduct of Islamic banking operations. Comprehensively, the guideline covers the general approach of MAS to Islamic banking which includes its admission. Apart from this, the guideline also deliberately provides the regulatory treatment of Islamic banking in Singapore. Although Islamic Banking in Singapore is treated the same as its conventional counterpart under the same regulatory framework, the issuance of this guideline is believed to provide a clear regulatory environment for financial institutions offering Islamic banking products in Singapore. Given that, any financial institutions offering Islamic banking are required to adhere to this guideline to ensure proper governance in the operation of Islamic banking.

\subsubsection{Shariah Advisory Board}

In general, in the Islamic finance industry, there is a need for Shariah advisors who guarantee that products and transactions in that particular industry are complying with Islamic law. Singapore also has this kind of Shariah Advisory Board, but in contrast to countries that have legal provisions for Islamic finance, Shariah Advisory Board in Singapore only bind Islamic financial institutions that appoint them. The Shariah Advisory Board is operated at the internal level of the Islamic financial institution only, not at the national level. They are tasked to ensure products and transactions are in compliance with Shariah. A person who is in the position of the Shariah Advisory Board is appointed by the bank itself and must carry out his duty to ensure that products and transactions are in accordance with the Islamic law and MAS Guidelines.

\subsubsection{International Standard for Islamic Banking and Finance}

To further enhance supervision and governance on IBF in Singapore, MAS became a Full Member of the Islamic Financial Services Board (IFSB) in April 2005 (IFSB, 2005). IFSB is an international standard-setting organization will facilitate its members with a proper standard to ensure the soundness of the overall Islamic financial services industry (IFSB, 2010). As a member of IFSB, financial institutions offering Islamic banking products and services are obliged to adhere to any standards issued by IFSB. For instance, in terms of corporate governance, IFIs in Singapore are required to comply with the 'Guiding Principles on Corporate Governance for Institutions Offering Only Islamic Financial Services' issued by IFSB standards for guidance on governance issues. Through this membership, further regulation and supervision will be applied parallel to the existing aforementioned MAS guideline to Islamic banking. This will further enhance the governance and supervision of IBF in Singapore.

\section{Legal Framework for Islamic Banking Disputes in Singapore}

With the tremendous growth of IBF, it is undeniable that conflicts pertaining to the contract, procedure, laws, ethics, and morals relating to Islamic banking transactions have emerged. Thus, precise and dedicated dispute resolution mechanisms are particularly essential to provide justice between the conflicting parties. Resolving dispute is significant to the extent that the customary dispute mechanisms and methods have been embedded within the legal system. This can be achieved through several processes such as arbitration, mediation, negotiation, collaborative law, and litigation.

International Journal of Management and Applied Research, 2019, Vol. 6, No. 4 
In the Islamic perspective, disputes should be approached in the most subtle and modest way which is based on religious values, traditional rituals of reconciliation and principle of coexistence (Rasyid, 2013). Hence, dispute resolution can be referred to a number of processes either through court-annexed processes or outside-court settlement by a third party based on the fundamentals of Islamic law (Oseni and Omoola, 2015). These processes may be adopted and utilized based on the type of dispute. Islamic finance products must comply with the Shariah law requirements; non-compliance often leads to dispute over the validity of the contract due to its failure to comply with the Shariah principles. Effective dispute resolution mechanism is important as it provides resolution for Islamic banking and finance disputes and allows the parties to seek recourse (Thomas, 2011).

Apart from litigation, disputes in IBF have been resolved through several Alternative Dispute Resolution (ADR) mechanisms such as mediation (sulh), arbitration (tahkim) and other innovative hybrid ADR mechanisms such as med-arb and arb-med. ADR mechanisms have been adopted by Muslims over 1,400 years ago and considered to be the source of legislation (Rasyid, 2013). The concept of ADR is permissible in Islam since the practice appears in the Qur'an in surah al-Hujarat, verse 10 which emphasized to make peace and reconciliation between two parties upon disputes arising between them. However, in actuality, it should be stressed that ADR should not be utilized in turning prohibited and haram practice into a permitted and halal practice and vice versa. When it comes to IBF dispute, the first litigation will be through the court system (Rasyid, 2013). Besides that, there is other available ADR litigation that can be an alternative option such as arbitration and mediation. In practice, the parties of the contract will include one specific clause where the parties are bound to refer to arbitration or mediation process in facing dispute arising from their concluded contract. Such practice alleviates any kind of procedural challenges if the dispute is brought to the court.

\subsection{Court System}

Shariah court has its own exclusive presence in Singapore as it only caters and provides legal solutions to Muslim personal matters such as divorce and other related matters (Thomas, 2011) stipulated under the Administration of Muslim Law Act (AMLA). Disputes concerning Islamic wealth management such as inheritance (faraidh), Islamic endowment (waqf), Islamic banking and finance cases fall under the civil court jurisdiction (Jani and Hassan, 2015). Majority references in Courts depend on the decisions from common law cases such as in Islamic Investment Company of the Gulf (Bahamas) Ltd v Symphony Gems NV \& Ors [WL 36969 Q.B. Com. Ct. Feb 13 2002, unreported], and Shamil Bank of Bahrain EC v Beximco Pharmaceuticals Ltd [2004] 1 W.L.R 1784. The launch of Singapore International Commercial Court (SICC) on January 2015 is seen to have provided some prospects for resolving IBF disputes because it has the jurisdiction to hear claims which are international and commercial in nature (SICC, 2019).

\subsection{Arbitration}

The process of arbitration is adopted particularly to ensure fair dealing and justice for conflicting parties. In definition, arbitration can be referred to as an alternative form of

International Journal of Management and Applied Research, 2019, Vol. 6, No. 4 
dispute resolution which does not require recourse to the courts (Jusic and Ismail, 2012). In Singapore, the adoption of arbitration in resolving disputes has also gained much momentum. In terms of court intervention, the Arbitration Act provides parties to refer the court on any related law matters and the question arising in the course of arbitration proceedings. The court does not possess any residual power to grant an application for which the law does not expressly provide. The Singapore courts are committed to minimal intervention for the arbitral process in Singapore. An essential aspect of arbitration in Singapore that needs to be taken into account is the arbitral choice of law (Jani and Hassan, 2015). This aspect of arbitration has given the parties the liberty to choose the governing law on the disputes based on their mutual consent. In cross-border arbitration for Islamic banking and finance, they refer to The United Nations Commission on International Trade Law (UNCITRAL) Arbitration Rules, with modifications included to accommodate Islamic finance dispute cases (Jusic and Ismail, 2012). Since Islamic banking and finance is treated as civil law matters, there is no opportunity for its disputes from being heard before Hakam or Islamic arbitrator who only exists in the Shariah court system.

\subsection{Mediation}

Mediation as an alternative dispute resolution is not only applicable to a dispute relating to criminal, custody, and inheritance, but mediation may also be applied in resolving transaction disputes. Under Islamic law, mediation is often conducted privately and such informal mechanism helps settlement (Rasyid, 2013). In Singapore, mediated settlement agreements are enforced by the courts as contracts (Anderson, 2017). On 10 January 2017, the Mediation Act was passed by the Singapore Parliament. Besides enacted seminal changes, Mediation Act also created a mechanism for a privately mediated settlement to be converted into a court order that is readily enforceable (Anderson, 2017). However, mediation programmes run by the Community Mediation Centres, Small Claims Tribunals, and the Tripartite Alliance for Dispute Management under the Ministry of Manpower the are not bound by the Mediation Act (Anderson, 2017).

\section{Growth and Prospect of Islamic Banking and Finance in Singapore}

Given its sound legal framework and political stability, the country has established itself as an international financial hub and one of the Four Asian Tigers. IFIs in Singapore can leverage the national competitive advantage (Porter, 1990) and further develop Islamic banking and finance in the country.

As a Muslim minority country neighbouring Malaysia and Indonesia, Singapore has ambitions towards the future development of the Islamic finance industry. The country has expressed its interest to be a leading Islamic financial centre and government supports are notable. In recent years, Singapore has improved its regulatory framework and tax treatments have been gradually introduced various financial products that are in accordance with Shariah.

International Journal of Management and Applied Research, 2019, Vol. 6, No. 4 
There are several foreign banks in Singapore which provides Islamic banking services such as Maybank Berhad, Commerce International Merchant Bankers Berhad (CIMB) and Noor Islamic Bank while the Overseas Chinese Banking Corporation (OCBC) is a local Singaporean bank offering Islamic banking services. In the year 2005, Maybank Berhad was the first bank to have introduced Shariah-compliant banking products and later to be followed by OCBC in 2007. In the same year, DBS Bank Limited established The Islamic Bank of Asia with an investment of US \$250 million which later became the first local Islamic bank in the country. The establishment of the Islamic Bank of Asia is believed to have assisted customers with their financial needs and demands through Shariah-compliant banking products. Unfortunately, in 2015, the DBS Bank, the parent bank of Islamic Bank of Asia, announced that Islamic Bank of Asia was unable to achieve economies of scale as intended and DBS Bank would progressively cease the operations of Islamic Bank of Asia (Tani, 2015).

The closure of Islamic Bank of Asia indicates that demands for Shariah compliant financial products are low in Singapore. Both Muslims and non-Muslims in Singapore exhibit low awareness of Islamic banking (Kepli, 2013). Although the Singapore market for Islamic retail banking is small and unable to reach its critical mass, the Singaporean government has been building off the infrastructure for Islamic capital market activities (Lai and Samers, 2017). Since the late 2000s, a number of Islamic bonds (Sukuk) have been issued in Singapore. Shariah banking assets in Singapore have grown 73\% since 2010 (Malaysia International Islamic Financial Centre, 2015). The Singaporean government also welcomes financial innovation in Islamic banking and this can be seen in the issuance of Waqf-Sukuk for Waqf development in the city centre of Singapore (Brown, 2008).

Through MAS, the government of Singapore made several legal adjustments to accommodate the operation of the Islamic banking and financial system in the country. Amendments were made to the Banking Act to facilitate Shariah-based financial products. Along with these amendments, MAS clarifying that the treatment of Islamic Banking products is already set out in regulations. In addition, MAS also amended the Income Tax Act through changes to the 2005 and 2006 budgets. Amendments to existing laws were carried out to adjust to the characteristics of the Islamic banking and financial system. Singapore waived the imposition of double stamp duties in Islamic transactions involving real estate (Stamp Duties Act, Chapter 312) and income tax and GST (goods and services tax) applications on some Islamic products were further clarified (Inland Revenue Authority of Singapore, 2016). This preferential tax treatment given by the government is one of the first steps that were issued to develop Islamic finance in Singapore, which indicates the aim of government to include Islamic financial services into part of Singapore's continuing development as a global financial centre (Kepli, 2013).

Support for IBF development in Singapore by the government did not stop there. Effective on April 8, 2015 the government made changes to the tax framework through the Stamp Duties (Remission) Rules 2015, providing provisions for remission of stamp duty to Islamic financial arrangements such as diminishing musharakah, istisna', and ijarah wa iqtina, provided that Islamic financial arrangements are supported by a

International Journal of Management and Applied Research, 2019, Vol. 6, No. 4 
Shariah council, body or committee formed for the purpose of providing guidance on compliance with Shariah law (Stamp Duties Act, Chapter 312).

\section{Conclusion}

As a conclusion, this study has identified that Singapore has adopted a flexible legal and regulatory approach to IBF. With a fine-tuning approach, a number of legal and regulatory provisions have been added on top of the existing legislation. In facilitating the operation of IBF in the country, the 'Guidelines on the Application of Banking Regulation to Islamic Banking' has been issued by MAS under the same regulatory framework as its conventional counterpart. It can be seen that IBF in Singapore is treated similarly as its conventional counterpart under the same regulatory framework. In addition, all matters relating to banking and finance including IBF will be referred under the civil court's jurisdiction.

In the absence of a national Shariah board, Islamic banks in Singapore are encouraged to appoint their own Shariah Advisory Board. This will allow flexibility on the overall operation of IBF and hence it gives further opportunity to embark into more innovative IBF products. In resolving disputes to IBF, civil courts are seen as the only option to resolve these matters. However, there exist other Alternative Dispute Resolution (ADR) mechanisms such as arbitration and mediation to resolve matters pertaining to financial and transactional matters. Despite these existing legal efforts, more proactive support from regulators and industry players is highly required in order to gain more legal recognition and to ensure further growth of IBF in Singapore.

\section{References}

1. Anderson, D. (2017), "Coming of age for mediation in Singapore", Singapore Academy of Law Journal, Vol. 29, No. 1, pp. 275-293.

2. Brown, R. A. (2008), "Islamic Endowments and the Land Economy in Singapore: The Genesis of an Ethical Capitalism, 1830-2007', South East Asia Research, Vol. 16, No. 3, pp. 343-403. https://doi.org/10.5367/000000008787133445

3. Inland Revenue Authority of Singapore (2016), List of Financial Services - An Excerpt of the GST Act, [Online] Available from: https://www.iras.gov.sg/IRASHome/uploadedFiles/IRASHome/GST/List $\% 20$ of\%2 0Financial\%20Services.pdf [Accessed on 7 April 2019].

4. Islamic Financial Services Board (IFSB) (2010), Establishment, [Online] Available from: https://www.ifsb.org/mission.php [Accessed on 7 April 2019].

5. Islamic Financial Services Board (IFSB) (2005), IFSB 3rd General Assembly and the 6th Meeting of the Council of the IFSB in Tehran, the Islamic Republic of Iran, [Online] Available from: https://www.ifsb.org/press full.php?id=66\&submit=more [Accessed on 7 April 2019].

International Journal of Management and Applied Research, 2019, Vol. 6, No. 4 
6. Jani, N. and Hassan, R, (2015), "Dispute Resolution in Singapore: Challenges and Opportunities for Islamic Finance", Journal of Islamic Economics, Banking and Finance, Vol. 11, No.4, 11-30.

7. Jusic, A. and Ismail, A. M. (2012), "Islamic Finance in the Western Balkans: Prospects and Regulatory Challenges", Arab Law Quarterly, Vol. 26, No. 2, pp. 193-210.

8. Kepli, M. (2013), "Islamic finance in singapore: Legal and regulatory challenges", Singapore Law Review, Vol. 31, No. 1, pp. 279-302.

9. Kuwait Finance House Research Ltd, (2013), Islamic Financial Regulatory Developments and Update Report.

10. Lai, K. and Samers, M. (2017), "Conceptualizing Islamic banking and finance: a comparison of its development and governance in Malaysia and Singapore", The Pacific Review, Vol. 30, No. 3, pp. 405-424. https://doi.org/10.1080/09512748.2016.1264455

11. Monetary Authority of Singapore (MAS) (2010), Guidelines on the Application of Banking Regulations to Islamic Banking. [Online] Available from: https://www.mas.gov.sg/-

/media/MAS/resource/legislation_guidelines/banks/guidelines/Guidelines_Banking Regns_to_IslamicBanking_Apr2010.pdf [Accessed on 7 April 2019].

12. Malaysia International Islamic Financial Centre (MIFC) (2015), Asia: Future Prospect for Islamic Finance, [Online] Available from: http://www.mifc.com/index.php?ch=28\&pg=72\&ac=152\&bb=uploadpdf [Accessed on 10 April 2019].

13. Oseni, U. A. and Omoola, S. O. (2015), "Banking on ICT: The relevance of online dispute resolution in the Islamic banking industry in Malaysia", Information \& Communications Technology Law, Vol. 24, No. 2,, pp. 205-223. https://doi.org/10.1080/13600834.2015.1067968

14. Porter, M. (1990), "The Competitive Advantage of Nations", Harvard Business Review, Vol. 68, No. 2, pp. 73-93.

15. Rasyid, A. (2013), "Relevance of Islamic Dispute Resolution Processes in Islamic Banking and Finance", Arab Law Quarterly, Vol. 27, No. 4, pp. 343-370.

16. Singapore International Commercial Court (SICC) (2019), Establishment of the SICC, [Online] Available from: https://www.sicc.gov.sg/about-the-sicc [Accessed on 7 April 2019].

International Journal of Management and Applied Research, 2019, Vol. 6, No. 4 
17. Singapore Law Watch (2018,), Mediation, Available from: https://www.singaporelawwatch.sg/About-Singapore-Law/Overview/ch-03mediation [Accessed on 6 July 2018].

18. Stamp Duties Act Chapter 312 (Islamic Financial Arrangements) (Remission) Rules 2015

19. Tani M, (2015), "DBS to Close Islamic Bank", Nikkei Asian Review [Online] Available from: https://asia.nikkei.com/Business/DBS-to-close-Islamic-bank [Accessed on 16 September 2018].

20. Thomas, R. J., (2011), "Islamic Banking and Finance - Regulatory Regimes in Malaysia and Singapore”, Singapore Law Review, Vol. 29, pp 165-190.

International Journal of Management and Applied Research, 2019, Vol. 6, No. 4 